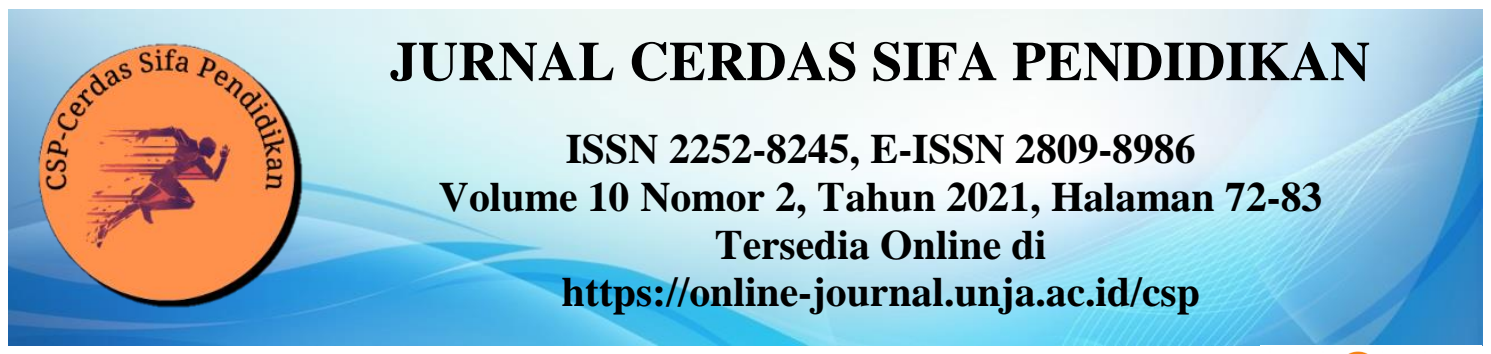

Research Article

OPEN ACCESS

\title{
Hubungan Koordinasi Mata Tangan Dan Kelenturan Terhadap Hasil Precision Shooting pada Atlet Petanque Jambi
}

\author{
Rasyono $^{1}$, Ade Setiowati ${ }^{2}$ \\ Prodi Kepelatihan Olahraga, FKIP, Universitas Jambi, Indonesia ${ }^{12}$ \\ Correspondence Author : rasyono@unja.ac.id
}

\begin{abstract}
ABSTRAK
Tujuan penelitian ini adalah untuk mengetahui tingkat koordinasi mata tangan dan kelenturan terhadap hasil precision shooting atlet petanque Jambi. Penelitian ini adalah penelitian merupakan penelitian kuantitatif dengan metode korelasional. Koordinasi mata tangan diukur menggunakan tes lempar tangkap bola, kelenturan diukur menggunakan tes sit and reach, sedangkan hasil Precisionshooting diukur dengan tes shooting yang aturannya mengikat dalam pertandingan nomor tersebut. Hasil penelitian menunjukkan ada korelasi antara koordinasi mata tangan $\left(\mathrm{X}_{1}\right)$ dan kelentukan $\left(\mathrm{X}_{2}\right)$ terhadap hasil precision shooting $(\mathrm{Y})$ pada atlet petanque Jambi dengan kategori kuat karena hasil perhitungan besar $\mathrm{R}$ (korelasi ganda) adalah sebesar $0,75 \approx 1$. Hasil $F_{\text {hitung }}$ sebesar 10,94 dan $F_{\text {tabel }} 3,55$. Hal ini berarti $F_{\text {hitung }}>F_{\text {tabel }}(10,94>3,55)$ yang artinya Ho ditolak dan Ha diterima. Dapat disimpulkan bahwa antara koordinasi mata tangan $\left(\mathrm{X}_{1}\right)$ dan kelentukan $\left(\mathrm{X}_{2}\right)$ terdapat hubungan terhadap hasil precision shooting (Y) atlet petanque Jambi.
\end{abstract}

Kata kunci : Koordinasi Mata Tangan, Kelenturan, Precision shooting

\section{Relationship Of Hand Eye Coordination And Flexibility To Precision Shooting Results In Petanque Jambi Athletes}

\begin{abstract}
The purpose of this study was to find out the level of hand eye coordination and flexibility to the results of precision shooting of jambi petanque athletes.This research is a quantitative study with correlational methods.Hand eye coordination is measured using the ball catch throw test, flexibility is measured using sit and reach tests, while Precisionshooting results are measured by shooting tests whose rules are binding in the number match.The results showed there was a correlation between hand eye coordination $(X 1)$ and flexibility $(X 2)$ to precision shooting $(Y)$ results in Jambi petanque athletes with strong categories because the result of large calculations $R$
\end{abstract}


(double correlation) was $0.75 \approx 1$.The result of $F$ calculates 10.94 and $F$ tables 3.55.This means $F$ calculates $>F$ table $(10.94>3.55)$ which means Ho is rejected and $\mathrm{Ha}$ is accepted.It can be concluded that between hand eye coordination (X1) and flexibility (X2) there is an association to the results of precision shooting (Y) of jamnque athletes.

Keywords: Hand Eye Coordination, Flexibility, Precision shooting

\section{PENDAHULUAN}

Olahraga merupakan sebuah disiplin ilmu yang sangat komplek karena bukan saja mempelajari tentang aktivitas fisik melainkan lebih dari itu yakni mempelajrai semua spek yang mempengaruhi aspek fisik tersebut. Ilmu pengetahuan yang mempengaruhi aspek fisik dikaji dalam berbagai disiplin ilmu yang berhubungan dengan faal, anatomi, teori latihan, belajar gerak, dan sebagainya.

Petanque merupakan olahraga permainan yang terus berkembang di dunia bahkan di Indonesia dan tidak terkecuali di Jambi juga. Olahraga Petanque sangat mengandalkan tingkat akurasi yang tinggi. Tingkat akurasi bisa diperoleh dengan proses latihan yang panjang kontinyu dan berkesinambungan dengan menerapkan teknik yang benar. Proses latihan yang baik tersebut akan berdampak pada otomatisasi gerak yang baik.

Perkembangan olahraga petanque membawa persaingan yang luar biasa. Selalu saja muncul juara baru serta rekor baru dalam setiap eventnya. Namun beberapa atlet berbakat mulai konsisten dengan rekor dan gelar juaranya yang menandakan tingkat otomatisasi dari kemampuanya mulai terbentuk.

Perkembangan sport science mengharuskan kita menjaring bibit atlet terbaik untuk dibina dengan benar. Dengan membina atlet berbakat dengan benar dan mengaplikasikan ilmu olahraga maka akan didapat atlet terbaik masa depan. Peneliti berasumsi bahwa olahraga petanque yang mengandalkan tingkat akurasi yang baik butuh didukung kondisi fisik yakni tingkat koordinasi mata tangan yang berfungsi untuk cekatan dan akurat melihat serta mengenai sasaran. Selain itu, juga harus didukung dengan kelenturan suoaya koordinasi serta harmonisasi gerak sempurna.

Gambaran serta masalah di atas menjadi dasar kuat penelitian ini untuk dapat menghasilkan sebuah gagasan dan bukti empiris terkait "Hubungan Koordinasi Mata Tangan dan Kelenturan Terhadap Hasil Precision Shooting Pada Atlet Petanque Jambi”.

Petanque adalah permainan sederhana. Tujuan dari permainan ini adalah untuk melempar bola besi (bosi) sehingga dekat dengan sasaran (boka/bola kayu). Seorang pemain atau tim memiliki skor atau poin dengan memiliki satu atau lebih dari bosi mereka lebih dekat ke boka dari posisi bosi lawan setelah semua bosi telah dilemparkan. Pemenangnya adalah pemain pertama atau tim untuk mencapai 13 poin.

Petanque is the world's most egalitarian sport. It can be savoured by almost anyone, regardless of age, gender or physical constraints (B.W Putman, 2011). Petanque merupakan olahraga yang sangat berkembang dan bias dimainkan oleh sega usia, jenis kelamin dan tanpa mempertimbangkan fisik khusus. Namun utuk menjadi seorang pemain yang bagus diperlukan penguasaan teknik yang baik. Technique and the training process is where we"re going to start. Technique is obviously the basis on which everything is built (Gilles Souef, 2015:29). Berikut adalah sekilas tentang teknik dasar bermain petanque. 


\section{Lemparan Menuju Titik Sasaran/Pointing (Throwing for pointing)}

Ponter/ Mendekati adalah aksi dimana pemain melempar bosi dengan tujuan mendekati posisi sasaran seperti menempatkan bosi disuatu tempat tertentu yakni dekat dengan boka, didepan bosi lawan dan sebaginya dengan tujuan menghalangi atau mengambil point (Vernet, Cedrik. 2019:22). Ponting biasanya dilakukan dengan jongkok namun itu tergantung dari kenyamanan pemian. Berikut Adalah jenis-jenis teknik ponting :

a. Roll ( Lemparan dengan menggelindingkan bola ke tanah)

Teknik lemparan dengan cara menggelindingkan bola menyusur tanah tanpa adanya lemparan melambung.Biasanya teknik ini dipakai dilapangan yang terbuat dari pasir ataupun batu kerikil kecil dan berjenis tanah keras.
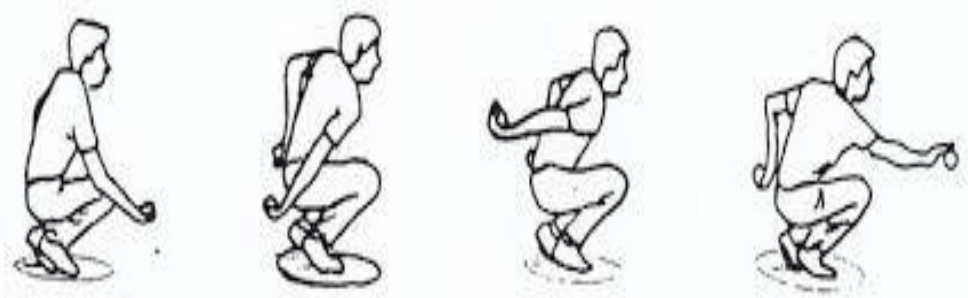

Gambar 1 Pointing Roll (Gesur)

b. Soft-Lob ( Lemparan Setengah Parabol)

Teknik lemparan dengan cara melempar bola sedikit melambung diudara. Biasanya teknik ini digunakan dilapangan yang berjenis tanah keras dan berbatu kerikil kecil.

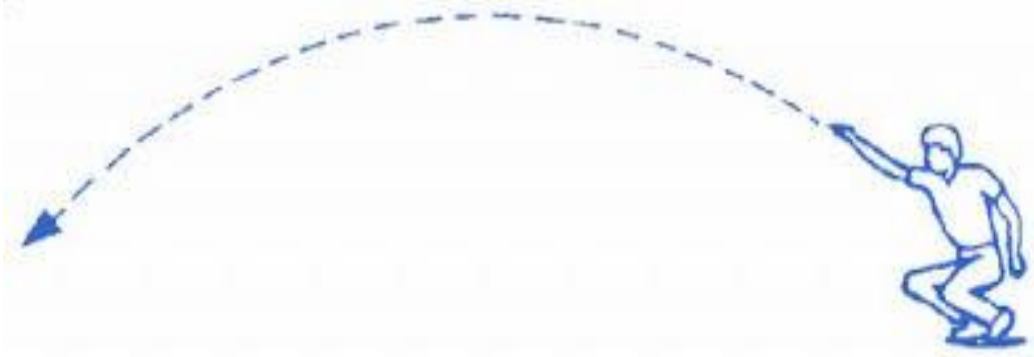

Gambar 2 Pointing soft-lob

c. High-Lob (Lemparan Tinggi Parabol)

Teknik lemparan dengan cara melempar bola melambung tinggi diudara. Biasanya teknik ini digunakan dilapangan yang berjenis tanah basah, berpasir, dan berkerikil kecil.

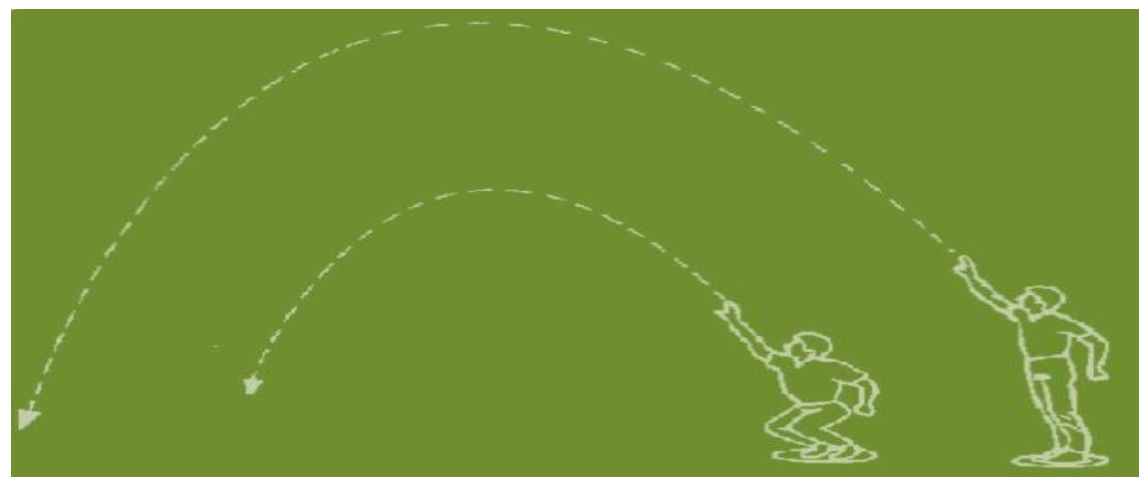

Gambar 3 Pointing High lob 
2. Lemparan untuk menembak (Throwing for shooter)

Shooting adalah jenis lemparan untuk mengusir bosi lawan dari boka target. Shooting atau menembak adalah melempar bosi dengan tujuan mengenai sasaran yakni bosi lawan untuk menjauhkan serta boka untuk menjadikan boka mati atau permainan selesai (Vernet, Cedrik. 2019:28). Ada beberapa cara melakukan Shooting, yaitu:

a. Shot On The Iron

Salah satu jenis Shooting yang perkenanan nya langsung presentuhan bola besi dengan bola besi tanpa menyentuh tanah terlebih dahulu.

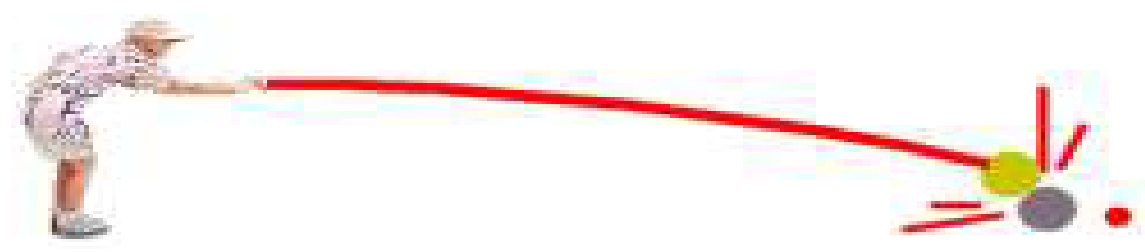

b. Short Shot

Gambar 4. Shooting on the iron

Salah satu jenis Shooting dimana bola yang dilemparkan terlebih dahulu menyentuh tanah dekat dengan bola sasaran sebelum menyentuh atau mengenai bola sasaran.

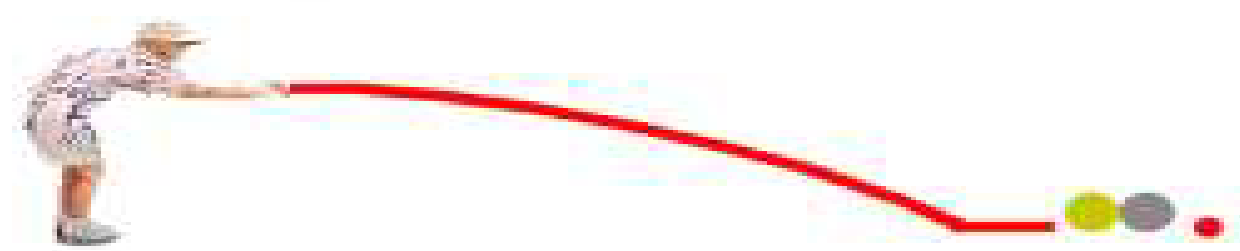

Gambar 5. Short shot

c. Ground Shot

Salah satu jenis Shooting dimana bola yang dilemparkan terlebih dahulu menyentuh tanah jauh dengan bola sasaran sebelum menyentuh atau mengenai bola sasaran.

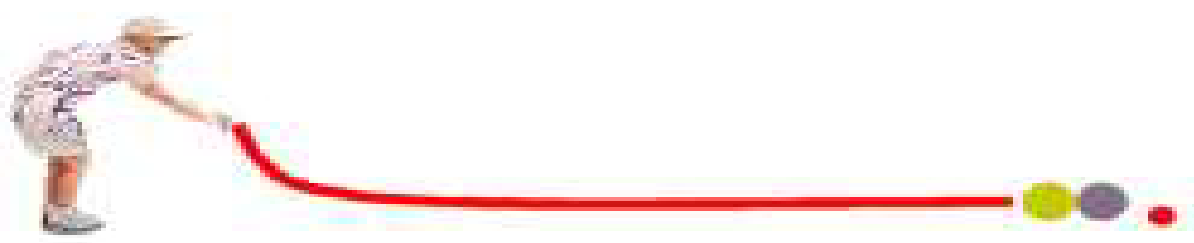

Gambar 6. Shooting Ground shot

Jenis Pertandingan Olahraga Petanque

Petanque dapat dimainkan dalam kategori atau nomor permainan dan nomor precision shooting.

1. Nomor Permainan

Adapun pada nomor permainan terdapat beberapa nomor yaitu : 


\section{Nomor triple}

Nomor ini merupakan permainan petanque yang dimainkan oleh 3 pemain melawan 3 pemain. Pada nomor triple setiap pemain memegang 2 bosi.

2. Nomor doubel

Adalah permainan petanque yang dimainkan oleh 2 pemain melawan 2 pemain. Pada nomor double setiap pemain memegang 3 bosi.

3. Nomor Single

Adalah permianan petanque yang dimainkan oleh 1 pemain melawan 1. Pada nomor single pemain memegang 3 bosi.

Untuk variasi dalam pertandingan bisa ditambah dengan double mix (putra dan putri) serta triple mix (dua putra dan satu putri atau sebaliknya). Namun tidak ada formula lain yang lazim digunakan selain ini.

Untuk lapngan nomor permianan dalam petanque menggunakan permukaan batu pecah, pasir atai tanah dengan ukuran standar internasional adalah lebar 4 meter dan panjang 15 meter. Untuk standar nasional boleh memainkan lapangan dengan panjang 12 meter dan lebar 3 meter. Berikut adalah gambar lapangan untuk nomor permainan petanque.

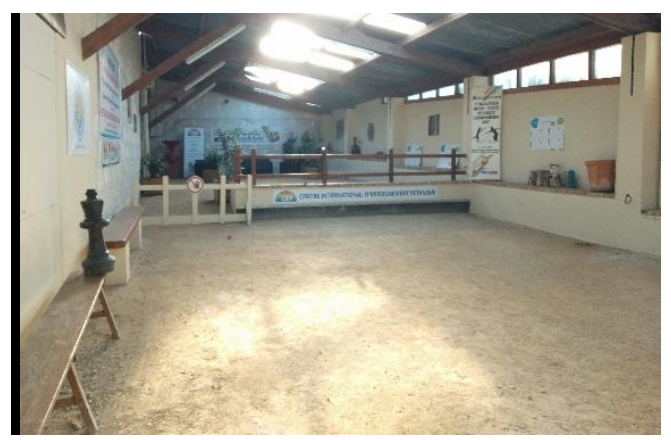

Gambar 7. Lapangan Nomor Permainan Petanque

\section{Nomor Precision Shooting}

Nomor precision Shooting dalam petanque adalah permainan petanque yang dimainkan dengan melempar kesasaran yang telah ditentukan dimana terdapat lima station dengan berbagai variasi sesuai peraturan yang berlaku. Adapun lapangan untuk nomor precision Shooting adalah sebagai berikut :

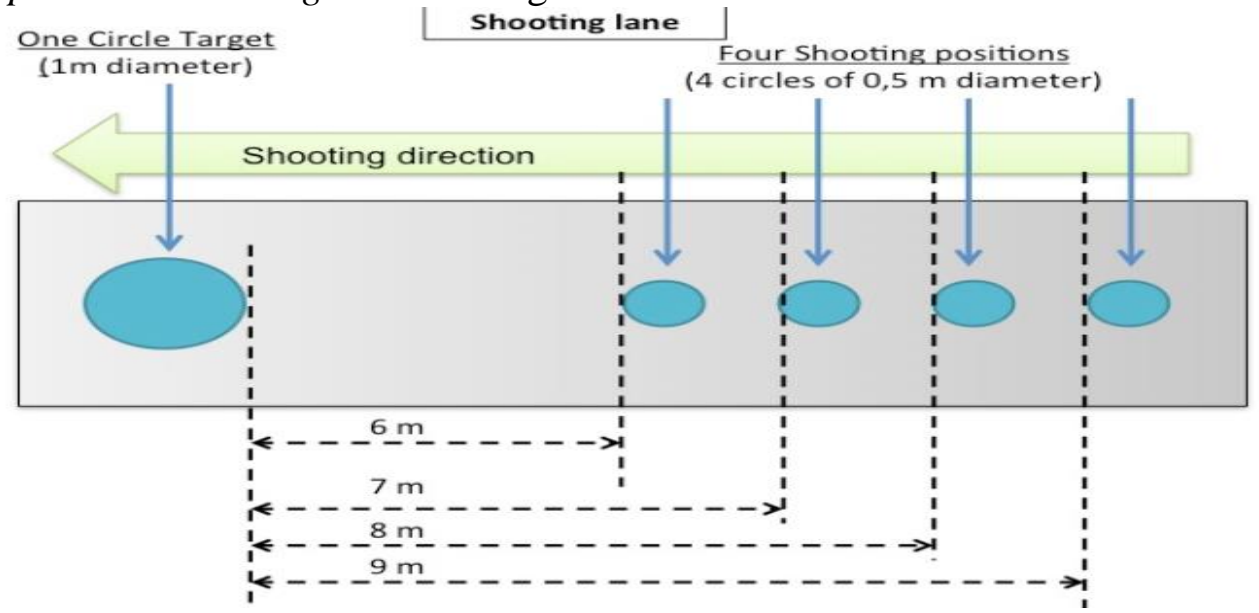

Gambar 8. Lapangan Precision Shooting 
Berikut adalah lima station yang harus dilempar dengan jarak sesuai line di atas 1. Station 1, dimana pemain melempar bosi tanpa penghalang One target boule

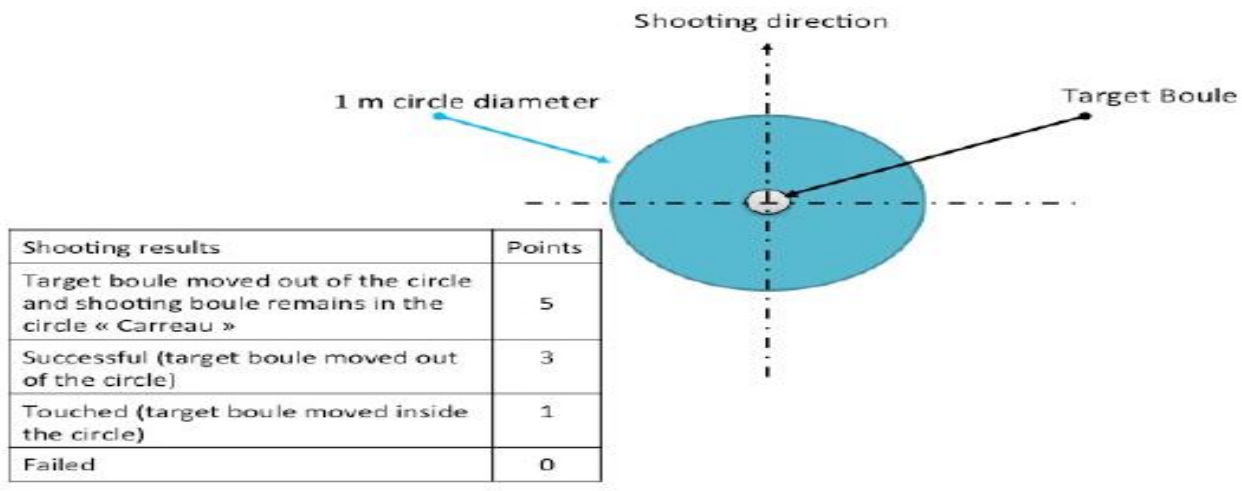

Gambar 9. Station 1 Pada Precision Shooting

2. Station 2, dimana pemain melempar bosi dengan penghalang boka Target boule behind the

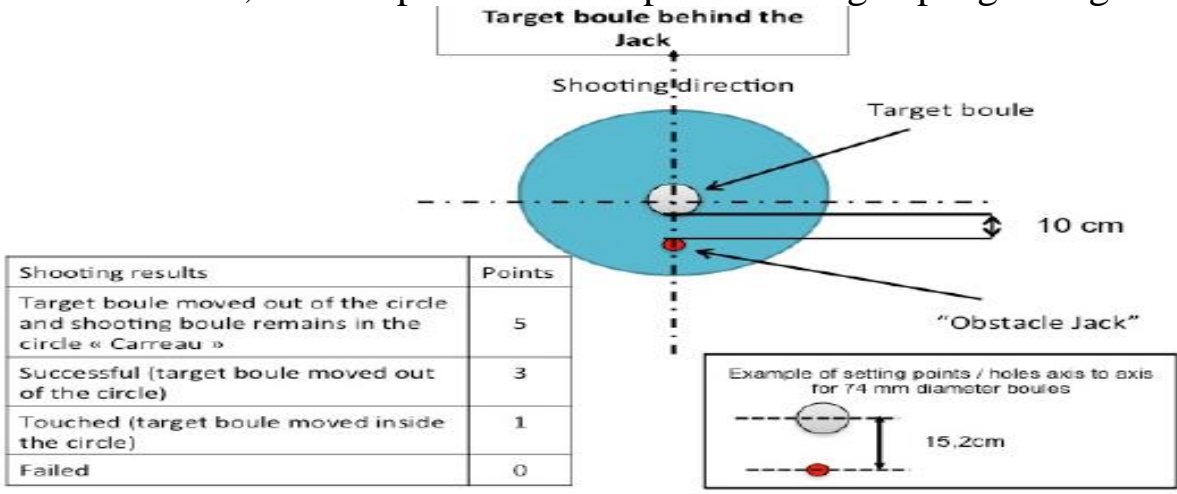

Gambar 10. Station 2 Pada Precision Shooting

(Sumber : FIPJP, 2017)

3. Station 3, dimana pemain melempar bosi diantara dua bosi

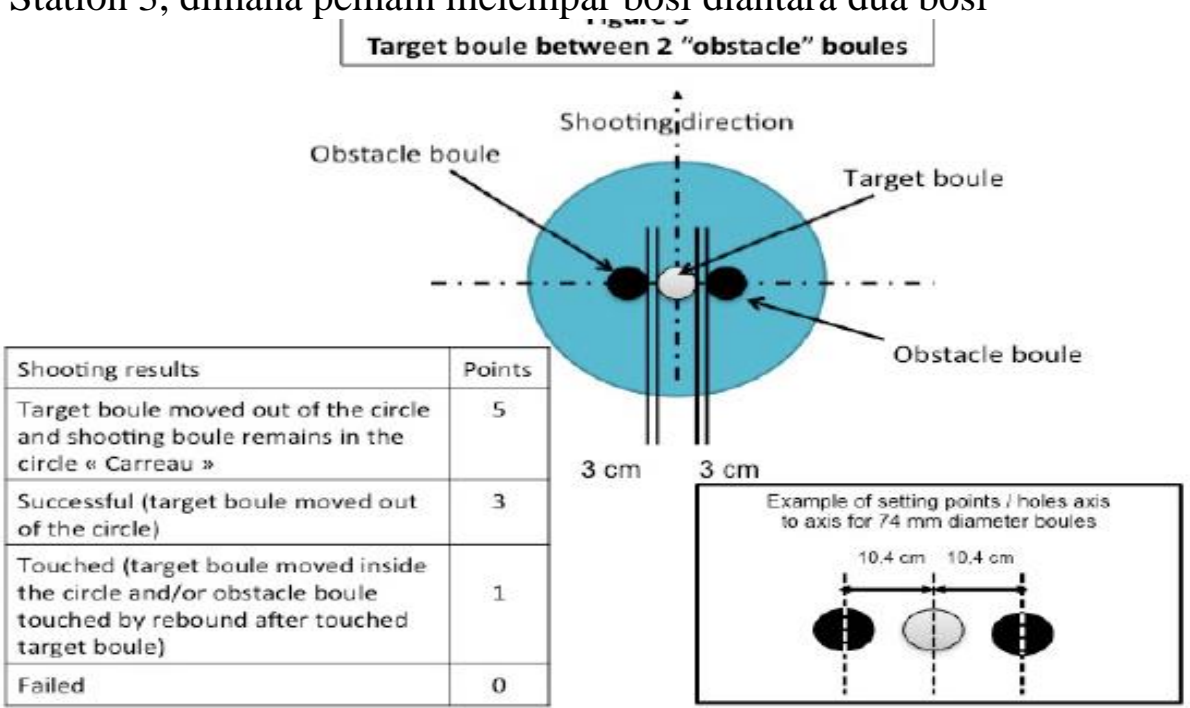

Gambar 11. Station 3 Pada Precision Shooting

(Sumber : FIPJP, 2017) 
4. Station 4, dimana pemain melempar bosi dengan penghalang bosi

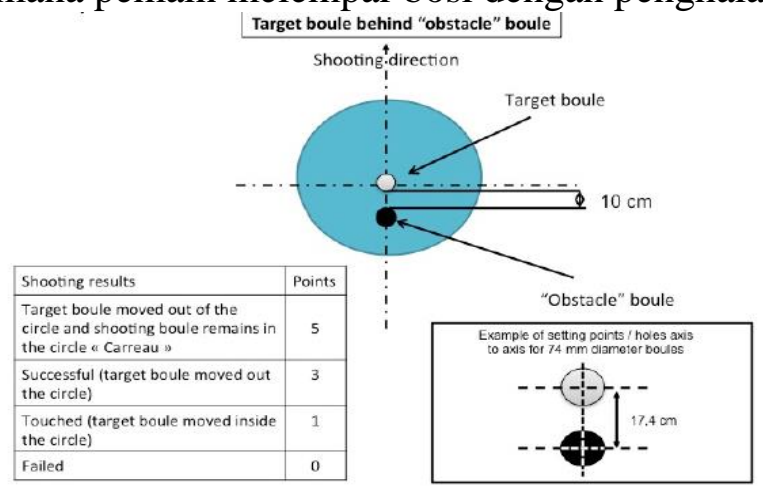

Gambar 12. Station 4 Pada Precision Shooting

5. Station 5, dimana pemain melempar boka tanpa penghalang

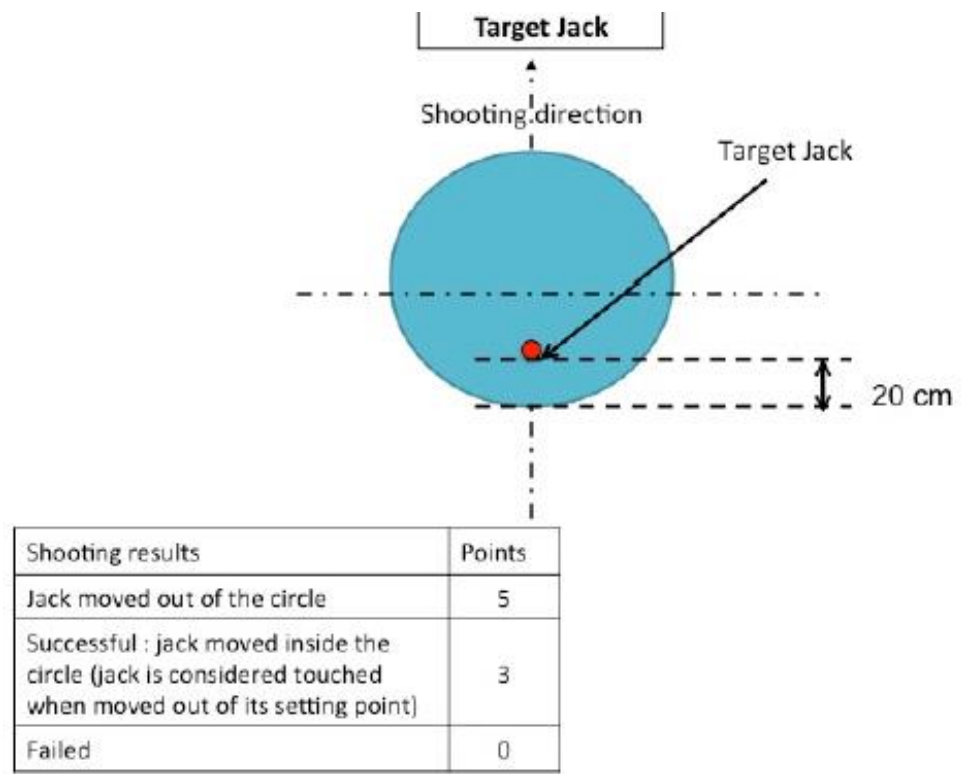

Gambar 13. Station 5 Pada Precision Shooting

Menurut Pelana (2016:118) shooting adalah jenis lemparan untuk mengusir bola lawan dari dekat bola kayu yang menjadi target. Nurhasan (2001:162) menambahkan bahwa : "Shooting adalah menembak bola ke sasaran. Souef (2015: 50) shooting tidak perlu deskripsi panjang: mengarahkan pada bola target (fokus pada titik bola target, bukan halangan bola) dan mencoba untuk mendaratkkan bola diatas bola target dan mendorongnya keluar lapangan. Dari beberapa sumber di atas dapat diambil kesimpulan , bahwa shooting adalah mengarahkan bola pada target dan mencoba mendaratkan bola kesasaran guna mengusir atau menjauhkan bola lawan dari boka.

Menurut Widiastuti (2015:17): "Koordinasi merupakan kemampuan untuk melakukan gerakan atau kerja dengan tepat dan efisien." Menurut Harsono (2018:160): "Atlet yang punya koordinasi yang baik adalah atlet yang juga mampu mengubah dan berpindah secara cepat dari pola gerak yang satu ke pola gerak yang lain sehingga gerakannya menjadi efisien." Dengan demikian koordinasi merupakan perwujudan peraturan terhadap proses motorik terutama terhadap kerja-kerja pada otot. Koordinasi diperlukan hampir di semua cabang olahraga pertandingan maupun perlombaan, sebab 
unsur-unsur dasar teknik gerak dalam cabang olahraga melibatkan singkronisasi dari beberapa kemampuan senada. Menurut PP.PBVSI (1995:61) yang dikutip oleh Kusnadi, Nanang dan Herdi Hartadji (2015:52) menjelaskan kegunaan atau manfaat dari koordinasi adalah :

1. Mengkoodinasi beberapa gerak agar menjadi satu gerakan yang utuh dan serasi.

2. Efisien dan efektif dalam penggunaan tenaga.

3. Untuk menghindari terjadinya cedera.

4. Baik dan tidaknya koordinasi kerja saraf, otot dan indera.

Koordinasi mata tangan mengkombinasikan kemampuan melihat dan kemampuan tangan, sebagai contoh dalam permainan tenis meja sebelum adanya gerakan memukul mata harus mengarah ke sasaran atau objek yang dituju, sedangkan tangan berfungsi untuk mengontrol pukulan agar sesuai pada target yang dituju. Menurut Bompa dalam Tatang Effendi (2010) mengemukakan bahwa dalam koordinasi mata dan tangan akan menghasilkan timming dan akurasi. Timming berorientasi pada ketepatan waktu, akurasi berorientasi pada ketepatan sasaran. Melalui timming yang baik, perkenaan antara tangan dengan objek akan sesuai dengan keinginan sehingga akan menghasilkan gerakan yang efektif. Akurasi akan menentukan tepat tidaknya obyek kepada sasaran yang dituju.

Kelenturan atau Fleksibilatas menurut Syafruddin (2012:111). "Kelentukan merupakan kemampuan tubuh untuk melakukan latihan-latihan dengan amplitudo gerakan yang besar atau luas". Menurut Bafirman (2008:119). "Tingkat kelentukan tubuh ditentukan oleh beberapa faktor, terutama jaringan ikat pada persendian, otot-otot, termasuk ligamen-ligamen,tendon dan bentuk kerangka persendian tersebut"..

Kegunaan kelentukan dalam olaharga adalah : Mempermudah dalam penguasaan teknik-tekinik tinggi, Mengurangi terjadinya cedera atlet, Seni gerak tercermin dalam kelentukan yang tinggi, Meningkatkan kelincahan dan ketepatan gerak

\section{METODE}

Penelitian ini merupakan jenis penelitian kuantitatif dengan mencari korelasional. Menurut Arikunto (2006:160) "Metodologi penelitian adalah carayang digunakan oleh peneliti dalam mengumpulkan data penelitian". Penelitian korelasi merupakan suatu penelitian yang melibatkan tindakan pengumpulan data guna menentukan, apakah adanya hubungan dan tingkat hubungan antara dua variabel atau lebih. Metode yang di gunakan adalah survei dengan tenik pengumpulan data menggunakan tes dan pengukuran.

Populasi dan sampel dalam penelitian ini merupakan seluruh atlet petanque Jambi yang memenuhi kriteria sebagai atlet. Kriteria tersebut adalah atlet yang pernah dan aktif mewakili Jambi pada event Petanque tingkat nasional. Sampel yang dipilih sebanyak 20 atlet.

Metode pengumpul data adalah suatu cara yang digunakan untuk memperoleh data. Instrumen pengumpul data merupakan suatu alat yang dapat digunakan oleh peneliti untuk mengumpulkan data (Mulyatiningsih, 2014:24). Dalam penelitian ini, metode pengumpul data yang digunakan adalah :

1. Tes Koordinasi Mata Tangan

Pengukuran terhadap koordinasi mata-tangan dilakukan dengan lempar tangkap bola tenis ke tembok sasaran. Mengukur koordinasi mata-tangan menggunakan cara lempar tangkap bola tenis ke tembok sasaran, (Ismaryati, 2008 : 54). 


\section{Tes Kelenturan}

Bentuk tes kelenturan yang sudah baku menggunakan tes sit and reach. Tes ini mengukur keluasan sendi punggung dengan mengukur jarak raihan ujung jari pada box dengan satuan $\mathrm{cm}$. Pelaksanaan tes seperti dalam gambar dibawah ini :

3. Tes Precision Shooting

Tes Precision Shooting mengacu pada nomor pertandingan Petanque yang telah dijelaskan sebelumnya di tinjaun kepustakan jenis nomor pertandingan petanque.

Teknik Analisis Data

Proses mengorganisasikan dan mengurutkan data kedalam pola, kategori dan satu uraian dasar sehingga dapat ditemukan tema dan dapat dirumuskan hipotesis kerja seperti yang didasarkan oleh data. data yang dikumpulkan, disusun, dan analisis korelasi.

\section{HASIL DAN PEMBAHASAN}

Hasil penelitian yang diperoleh dari tes disajikan dalam bentuk angka statistik. Angka-angkat tersebut memberikan gambaran nyata kondisi dilapangan. Data keseluruhan di atas lalu dirincikan kedalam rumus korelasi antar variabel sehingga memberi hasil sesuai dengan tujuan penelitian. Berikut adalah perhitungan statistik hasil penelitian yang menggambarkan korelasi antar variabel yang diteliti.

1. KORELASI $X_{1}$ dengan $\mathrm{Y}$

Tabel 2. Korelasi $X_{1}$ dengan Y

\begin{tabular}{|c|c|}
\hline SIMBOL STATISTIK & NILAI STATISTIK \\
\hline $\mathrm{n}$ & 20 \\
\hline$X_{1}$ & 319 \\
\hline$Y$ & 515 \\
\hline$\sum X_{1}^{2}$ & 5247 \\
\hline$\sum Y^{2}$ & 13721 \\
\hline$\sum X_{1} Y$ & 8413 \\
\hline
\end{tabular}

$$
\begin{aligned}
r X_{1} Y & =\frac{n\left(\sum X_{1} Y\right)-\left(\sum X_{1}\right)\left(\sum Y\right)}{\sqrt{\left\{n \sum X_{1}{ }^{2}-\left(\sum X_{1}\right)^{2}\right\} \cdot\left\{n \sum Y^{2}-\left(\sum Y\right)^{2}\right\}}} \\
r X_{1} Y & =\frac{20(8413)-(319)(515)}{\sqrt{\left\{20.5247-(319)^{2}\right\} \cdot\left\{20.13721-(515)^{2}\right\}}}=0,735
\end{aligned}
$$

2. KORELASI $X_{2}$ dengan $Y$

Tabel 3 KORELASI $X_{2}$ dengan $Y$

SIMBOL STATISTIK NILAI STATISTIK

$\mathrm{n}$

20 


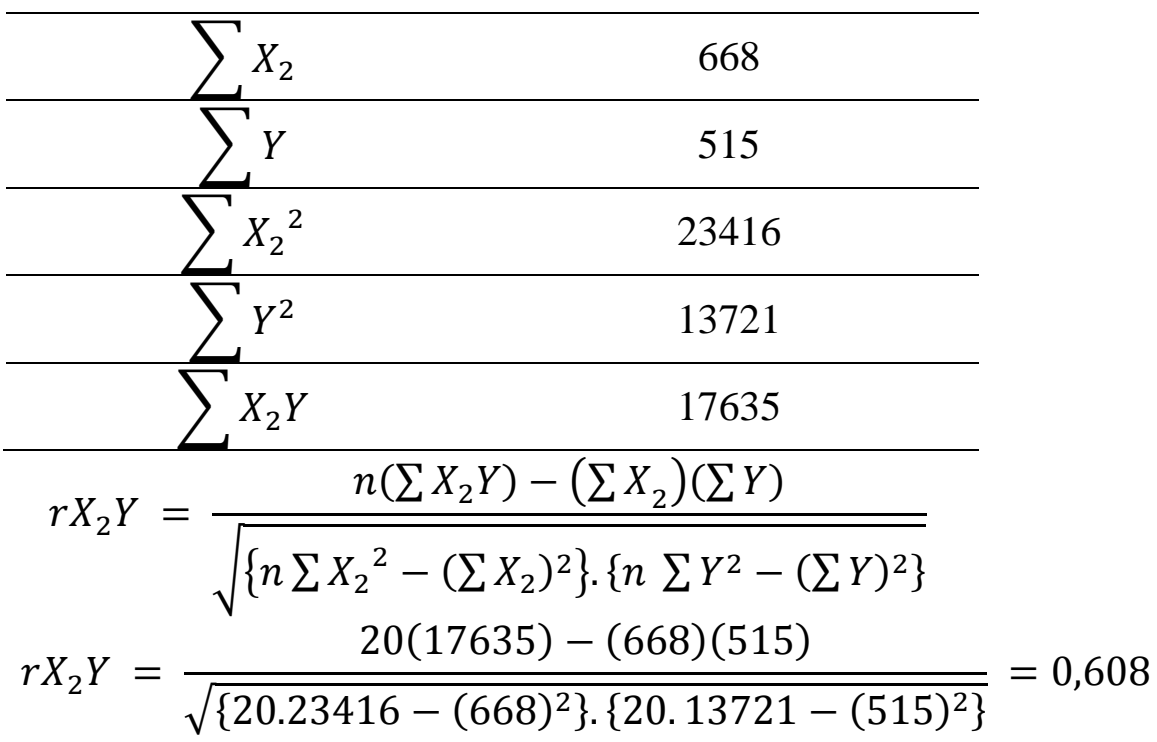

3. Korelasi $X_{1}$ dengan $X_{2}$

Tabel 4 KORELASI $X_{1}$ dengan $X_{2}$

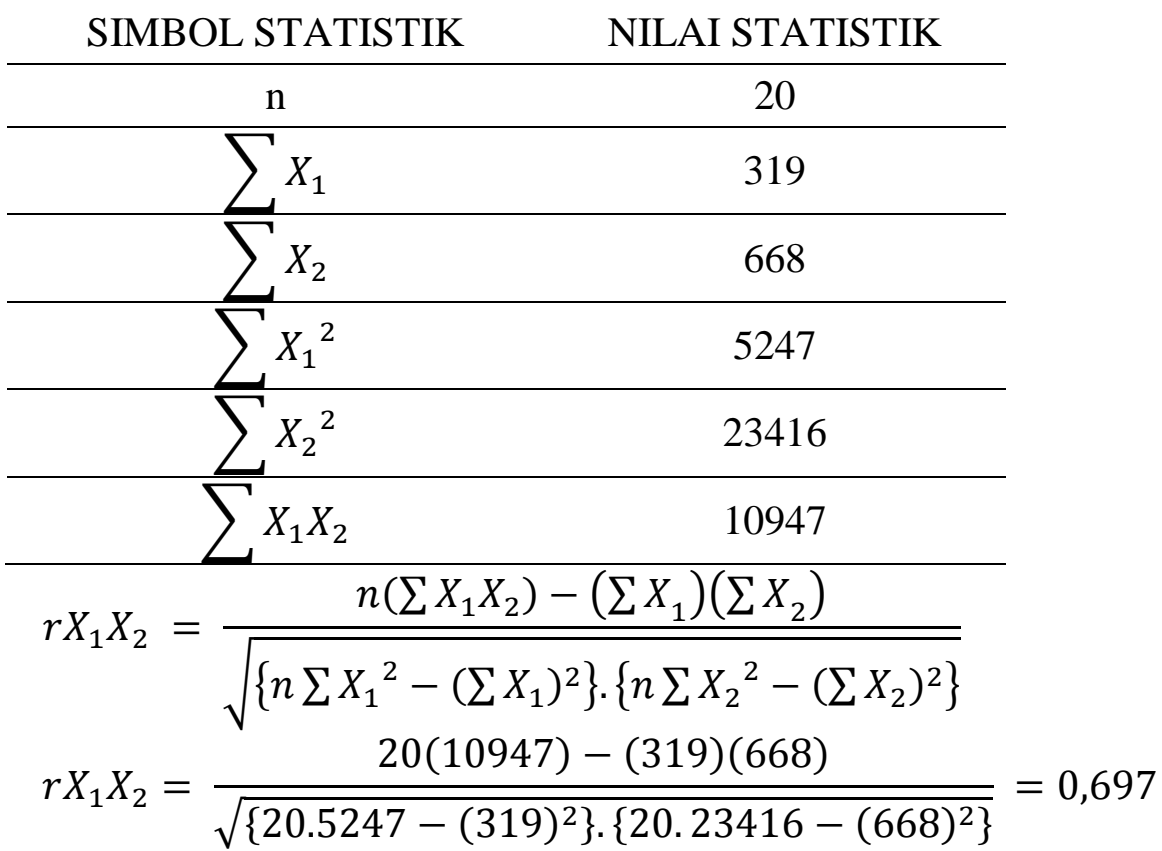

4. Rumus Analisis Korelasi Ganda (R)

$$
\begin{gathered}
R X_{1} X_{2} Y=\sqrt{\frac{b_{1} X_{1} Y+b_{2} X_{2} Y-2 b X_{1} Y \cdot b X_{2} Y \cdot b X_{1} X_{2}}{1-b X_{1} X_{2}}} \\
R X_{1} X_{2} Y=\sqrt{\frac{0,735^{2}+0,608^{2}-2 \cdot(0,735)(0,608)(0,697)}{1-0,697^{2}}} \\
R X_{1} X_{2} Y=\sqrt{\frac{0,910-0,623}{0,514}}=\sqrt{\frac{0,287}{0,514}}=\sqrt{0,56}=0,75 \approx 1
\end{gathered}
$$

Dari hasil perhitungan tersebut dapat dikatakan bahwa terdapat hubungan (korelasi) antara koordinasi mata tangan $\left(\mathrm{X}_{1}\right)$ dan kelentukan sit and reach $\left(\mathrm{X}_{2}\right)$ terhadap 
hasil precision shooting (Y) pada atlet petanque Jambi. Korelasi antara koordinasi mata tangan $\left(\mathrm{X}_{1}\right)$ dan kelentukan sit and reach $\left(\mathrm{X}_{2}\right)$ terhadap precision shooting $(\mathrm{Y})$ pada atlet petanque Jambi kuat karena hasil perhitungan di atas besar $\mathrm{R}$ (korelasi ganda) adalah sebesar $0,75 \approx 1$. Sedangkan untuk menyatakan besar kecilnya kontribusi variabel $\mathrm{X}_{1}$ dan $\mathrm{X}_{2}$ terhadap variabel $\mathrm{Y}$ atau koefisien determinan $=\mathrm{R}^{2} \times 100 \%$ atau $(0,75 \times 100 \%=$ $56,25)$. berikut:

Selanjutnya untuk mengetahui keberartian korelasi ganda (R) dihitung uji $\mathrm{F}$

$$
F_{\text {Hitung }}=\frac{\frac{R^{2}}{k}}{\frac{\left(1-R^{2}\right)}{(n-k-1)}}=\frac{\frac{0,75^{2}}{2}}{\frac{\left(1-0,75^{2}\right)}{(20-2-1)}}=\frac{0,28125}{0,0257}=10,94
$$

Kriteria pengujian nilai $\mathrm{F}$ hitung terhadap $\mathrm{F}$ table adalah:

a) Jika nilai $\mathrm{F}_{\text {hitung }}<\mathrm{F}$ table maka Ho diterima dan $\mathrm{H} 1$ ditolak.

b) Jika nilai $\mathrm{F}_{\text {hitung }}>\mathrm{F}_{\text {table }}$ maka Ho ditolak dan $\mathrm{H} 1$ diterima.

Berdasarkan hasil perhitungan di atas diperoleh $\mathrm{F}$ hitung sebesar 10,94, F tabel pada taraf $\alpha=0,05$, df $1=\mathrm{k}-1=3-1=2$ dan df $2(\mathrm{n}-\mathrm{k}=20-2=18)$ diperoleh nilai $\mathrm{F}$ tabel 3,55. Hal ini berarti $F$ hitung $>\mathrm{F}$ tabel $(10,94>3,55)$ yang artinya Ho ditolak dan Ha diterima. Dapat disimpulkan bahwa antara koordinasi mata tangan $\left(\mathrm{X}_{1}\right)$ dan kelentukan sit and reach $\left(\mathrm{X}_{2}\right)$ terdapat hubungan terhadap hasil precision shooting $(\mathrm{Y})$ atlet petanque Jambi.

Hasil penelitian yang menujukkan angka statistik bahwa ada korelasi antara koordinasi mata tangan $\left(\mathrm{X}_{1}\right)$ dan kelentukan sit and reach $\left(\mathrm{X}_{2}\right)$ terhadap hasil precision shooting (Y) memberi gambaran bahwa untuk mencari bibit atlet petanqe unsur fisik tersebut sangat dibutuhkan. Selain untuk mencari bibit atlet metode untuk meningkatkan koordinasi dan kelenturan perlu diterapkan dalam program latihan yang dilakukan pada atlet petanque.

\section{KESIMPULAN}

Hasil korelasi $X_{1}$ dengan $\mathrm{Y}$ sebesar 0,735 dan hasil korelasi $X_{2}$ dengan $\mathrm{Y}$ sebesar 0,608. Sehingga terdapat korelasi antara koordinasi mata tangan $\left(X_{1}\right)$ dan kelentukan sit and reach $\left(\mathrm{X}_{2}\right)$ terhadap precision shooting $(\mathrm{Y})$ pada atlet petanque Jambi kategori kuat karena hasil perhitungan besar $\mathrm{R}$ (korelasi ganda) adalah sebesar $0,75 \approx 1$. Dari $\mathrm{F}$ hitung diperoleh sebesar 10,94 dan $\mathrm{F}$ tabel 3,55 . Hal ini berarti $\mathrm{F}$ hitung $>\mathrm{F}$ tabel $(10,94>3,55)$ yang artinya Ho ditolak dan Ha diterima. Dapat disimpulkan bahwa antara koordinasi mata tangan $\left(\mathrm{X}_{1}\right)$ dan kelentukan sit and reach $\left(\mathrm{X}_{2}\right)$ terdapat hubungan terhadap hasil precision shooting (Y) atlet petanque Jambi.

\section{DAFTAR RUJUKAN}

Ambarukmi, D.A.dkk.2007. Pelatihan Pelatih FisikLevel I. Deputi Bidang Peningkatan Prestasi dan IPTEK Olahraga. Kemenpora.

Arikunto. 2006. Prosedur Penelitian Suatu Pendekatan Praktek. Jakarta : PT. Rineka Cipta.

B.W. Putman. 2011. PETANQUE The Greatest Game You Never Heard Of. French.

Bafirman. 2008. Buku ajar Pembentukan Kondisi Fisik: UNP Pres.

F.I.P.J.P and LE C.I.E.P. 2006. Pedagogical Leaflet. France : Plastico Rototech.

FFPJP. 2014. Rules For the individual shooting world championship Gilles Souef. 
Gilles SOUEF. 2015. The Winning Trajectory : Petanque - Training and technique. France: Copymedia.

Harsono. 2018. Latihan Kondisi Fisik untuk Atlet Sehat Aktif. Bandung: PT Remaja Rosdakarya.

Ismaryati.2008. Tes dan Pengukuran Olahraga. Cetakan 2. Surakarta: LPP UNS dan UNS Press

Iwan hermawan, M.Pd. 2012. Gerak dasar permainan olahraga Petanque. Jakarta : Deputi Pemberdayaan Olahraga.

Kusnadi, Nanang, Herdi Hartadji (2015). Ilmu Kepelatihan Lanjutan. Tasikmalaya: PJKR FKIP UNSIL

Mulyatiningsih. 2014. Metode Penelitian Terapan Bidang Pendidikan. Yogyakarta: Alfabeta Bandung

Nurhasan (2001) Tes dan Pengukuran dalam Pendidikan Jasmani. Jakarta, penerbit Direktorat Jendral Olahraga.

Pelana, R. 2016. "Hubungan Kekuatan Otot Tungkai Dan Keseimbangan Statis Dengan Hasil Shooting Pada Atlet Klub Petanque". Prosiding Seminar Nasional Maret 2016. http://pasca.um.ac.id/conferences/index.php/SNPJ/article/download/996/667

Sudjana. (2005). Metode Statistika. Bandung: Tarsito

Sukadiyanto (2011). Pengantar Teori dan Metodologi Melatih Fisik. Bandung: CV. Lubuk Agung.

Syafruddin. 2012. Kondisi Fisik. Padang : FIK UNP

Usman, Moh. Uzer. (2000). Menjadi Guru Profesional. Bandung: Remaja Rosdakarya

Vernet, Cedrik. 2019. Olahraga Petanque : Petunjuk Pemain, Memo Wasit, Aturan Internasional. Jakarta : Kridatama Adara Konsep

Widiastuti, 2015. Tes dan Pengukuran Olahraga. Jakarta: PT RajaGrafindo Persada 